\title{
Effect micro-nutrients and farm yard manure on soil properties and yield of maize (Zea mays 1.) in lower Indo-Gangetic Plain of Uttar Pradesh
}

\author{
Devesh Pratap ${ }^{1}$, J. Singh ${ }^{2}$, Rahul Kumar ${ }^{3}$, Om Kumar ${ }^{1}$ and K.S. Rawat ${ }^{4} *$ \\ ${ }^{1}$ Centre for Environment Science and Climate Resilient Agriculture, IARI, New Delhi, INDIA \\ ${ }^{2}$ Division of Agricultural Physics, IARI, New Delhi, INDIA \\ ${ }^{3}$ Department of Soil Science \& Agricultural Chemistry, School of Forestry and Environment, SHIATS, Allahabad \\ (U.P.), INDIA \\ ${ }^{4}$ Centre for Remote Sensing and Geo-Informatics, Sathyabama University, Chennai, INDIA \\ *Corresponding author. E-mail: ksr.kishan@gmail.com
}

Received: June 2, 2015; Revised received: November 3, 2015; Accepted: February 19, 2016

\begin{abstract}
The objective of the study to find the suitable treatment combination between the combination of compaction, micronutrients and farm yard manure, which enhanced physical, chemical properties of soil and yield for alluvial soil. The maximum particle density $(3.01 \mathrm{~g} / \mathrm{cc})$, water holding capacity $(58.23 \%)$ and pore space $(63.40 \%)$ were observed in the treatment $T_{3}\left(C_{3} l_{3} M_{3}\right)$, whereas maximum bulk density $(1.09 \mathrm{~g} / \mathrm{cc})$ was observed in the treatment $T_{1}$ $\left(\mathrm{C}_{1} \mathrm{l}_{1} \mathrm{M}_{1}\right)$. The maximum EC $\left(0.58 \mathrm{dS} \mathrm{m}^{-1}\right)$, Organic carbon $(0.66 \%)$, available nitrogen $(279.76 \mathrm{~kg} / \mathrm{ha})$, phosphorous (19.62 $\left.\mathrm{kg} \mathrm{P}_{2} \mathrm{O}_{5} / \mathrm{ha}\right)$ potash (194.90 $\left.\mathrm{kg} \mathrm{K} \mathrm{O} / \mathrm{ha}\right)$, zinc $(0.65 \mathrm{ppm})$ and sulfur $(14.89 \mathrm{ppm})$ were found in treatment $\mathrm{T}_{3}$ $\left(C_{3} I_{3} M_{3}\right)$. The electrical conductivity gradually increased from control $\left(C_{0} l_{0} M_{0}-0.45\right)$ to $T_{3}\left(C_{3} I_{3} M_{3}-0.58\right) d S m^{-1}$. The maximum dry weight, test weight and yield were found in the treatment $\mathrm{T}_{2}\left(\mathrm{C}_{2} \mathrm{I}_{2} \mathrm{M}_{2}\right)$ viz., $154.43,(230.33$ and 50.50 qha $^{-1}$ respectively for alluvial soil.
\end{abstract}

Keywords: Farm yard manure (FYM), Maize yield, Micronutrients, Soil compaction

\section{INTRODUCTION}

Maize is the most widely distributed crops of the world. It is cultivated in tropics, sub-tropics and temperate regions. India ranks fourth in the world and it shared area (4.88\%) and production (2.55\%) in 2012 (FAO 2012). The area of maize in India has been increased from 7.8 to 8.8 (1.1 Mn Hectare) and production from 15 to 22 (7 Mn Mt) during 2006-07 to 2011-12. In Uttar Pradesh, the production and area of maize is $1.1 \mathrm{Mn}$ tonne and $0.8 \mathrm{Mn}$ hectares, respectively (India Maize Summit 14).The Upper Indo-Gangetic Plain of Uttar Pradesh is an important producer of maize in the state. Maize is grown in as many as 25 districts in Uttar Pradesh, but Bulandshahar, Jaunpur, Ghaziabad, Bahraich, Farrukhabad and Gonda are the main producing districts. Maize utilized for direct consumption over the year and increasing commercial demand, presently poultry and cattle feed 61 percent starch and food processing 19 percent in 2012-13 (India maize summit, 2014).

Soil compaction has a severe problem in mechanized agriculture and it influence on many soil properties and on crop yield. The soil is compacted by an intensive use of machinery during the wheat, barley and second crop maize production. It increases bulk density and penetrometer resistance while it reduces penetrability of roots to soil (Unger and Kaspar, 1994) and crop yield (Husnjak et al., 2002). Soil compaction may significantly impair maize productivity by decreasing the aeration, soil water storage and crop water use efficiency (Kumar et al., 2012a; 2012b). The effect of soil compaction on maize yields has been study comprehensively due to decrease soil productivity associated with mechanization. Farm Yard Manure (FYM) is a good source of nutrients and contributed towards build up of organic matter in soil. It helps to improve and conserve the fertility of soil. Maize responded markedly to graded levels of FYM and showed spectacular response to integration of FYM and fertilizer, plausibly through the activity and population of beneficial soil organisms in the soil. The main objective of the study was how to improved yield of maize through soil manipulation and nutrient management.

\section{MATERIALS AND METHODS}

Study area: An experiment was conducted at Research Farm, Department of Soil Science, Sam Higginbottom Institute of Agriculture, Technology and Sciences, Allahabad, U.P. It is situated 25024'08.71-N latitude and $81^{\circ} 50^{\prime} 16.95 " \mathrm{E}$ longitude, and along the Yamuna River catchment and 98 meter above the mean sea level.

Treatment combination:

$\mathrm{T}_{0}$ - Control $\left(\mathrm{C}_{0} \mathrm{I}_{0} \mathrm{M}_{0}\right)$

$\mathrm{T}_{1^{-}}\left(\mathrm{C}_{1} \mathrm{I}_{1} \mathrm{M}_{1}\right) @ 125 \mathrm{~kg}$ Roller 3 times + @25\% RDF 
$\left(\mathrm{NPK}+\mathrm{ZnSO}_{4}\right)+\mathrm{FYM} @ 2.5 \mathrm{tha}^{-1}$

$\mathrm{T}_{2^{-}}\left(\mathrm{C}_{2} \mathrm{I}_{2} \mathrm{M}_{2}\right) @ 125 \mathrm{~kg}$ Roller 6 times $+@ 50 \%$ RDF $\left(\mathrm{NPK}+\mathrm{ZnSO}_{4}\right)+\mathrm{FYM} @ 5 \mathrm{tha}^{-1}$

$\mathrm{T}_{3}-\left(\mathrm{C}_{3} \mathrm{I}_{3} \mathrm{M}_{3}\right) @ 125$ kg Roller 9 times + @100\% RDF $\left(\mathrm{NPK}+\mathrm{ZnSO}_{4}\right)+\mathrm{FYM} @ 10 \mathrm{tha}^{-1}$

Mechanical and chemical analysis: Mechanical analysis was done by "Bouyoucous hydrometer method". The bulk density, particle density and percentage pore space determined by cylinder method. Chemical analysis of soil viz., $\mathrm{pH}, \mathrm{EC}$, organic carbon, available nitrogen, available phosphorous, available potassium, sulfur and zinc of soil were determined using $\mathrm{pH}$ and Ec meter as described by Jackson (1958), Walkley and Black (1934) method, Alkaline permanganate method Subbiah and Asija (1956), Olsen's colorimetric method (Olsen et al., 1954), Flame photometric method Blancher (1986), Lindsay and Norvell (1978).

Statistical analysis: Randomized block design was used in experiment with three replications. The different plant and soil parametric data recorded at the field were used for statistical analysis method as given by Fisher (1960). The significant and non significant of treatment effect was judged with the help of ' $F$ ' variance ratio test calculated ' $F$ ' at $5 \%$ level of significance.

\section{RESULTS AND DISCUSSION}

Effect micro-nutrients and farm yard manure on soil physical properties: The maximum particle density $(3.01 \mathrm{~g} / \mathrm{cc})$, water holding capacity $(58.23 \%)$ and pore space $(63.40 \%)$ were observed in the treatment $\mathrm{T}_{3}$ $\left(\mathrm{C}_{3} \mathrm{I}_{3} \mathrm{M}_{3}\right)$. The maximum bulk density $(1.16 \mathrm{~g} / \mathrm{cc})$ was observed in the treatment $\mathrm{T}_{1}\left(\mathrm{C}_{1} \mathrm{I}_{1} \mathrm{M}_{1}\right)$ as compared to control $(1.15 \mathrm{~g} / \mathrm{cc})$. It might be due to the greater level of organic $\mathrm{C}$ content maintained as a result of applications of FYM. Level of compaction, micro-nutrient and FYM did not significantly changed bulk density (g/cc). It was also observed the bulk density $(\mathrm{g} / \mathrm{cc})$ in soil was gradually decreased with application of the FYM, NPK and micro-nutrient (Laiho et al., 2004; Schjonning et al., 1994).The presence of FYM improved the water holding capacity $(\%)$ of soil. It's contains higher amount of organic matter, silt and clay particle. As these indicated an enrichment of fine fractions i.e. Silt and clay a part from the retention of dissolved organic matter (OM) leading to change in physical properties of soil. Mulholland et al. (1999) reported that water holding capacity $(\%)$ of soil was increased by moderate degree of compaction and decreased by heavy compaction. Effect of micro-nutrients and farm yard manure on soil chemical properties: Soil chemical properties viz. EC, organic carbon, available NPK and sulfur showed a significant change whereas $\mathrm{pH}$ and available zinc showed non significant changes. The $\mathrm{pH}$ values showed gradually decreases with increase soil compaction, micronutrient and farm yard manure application (Aphale et al., 2005; Tracy and Zhang, 2008). The maximum EC $\left(0.58 \mathrm{dS} \mathrm{m}^{-1}\right)$, Organic carbon $(0.66 \%)$, available nitrogen $(279.76 \mathrm{~kg} / \mathrm{ha})$, phosphorous (19.62 $\mathrm{kg} / \mathrm{ha})$ potash $(194.90 \mathrm{~kg} / \mathrm{ha})$, zinc $(0.65 \mathrm{~kg} / \mathrm{ha})$ and sulfur $(14.89 \mathrm{~kg} / \mathrm{ha})$ were found in treatment $\mathrm{T}_{3}$ $\left(\mathrm{C}_{3} \mathrm{I}_{3} \mathrm{M}_{3}\right)$. The electrical conductivity was gradually increased from treatment control $\left(\mathrm{C}_{0} \mathrm{I}_{0} \mathrm{M}_{0}\right) 0.45$ to $\mathrm{C}_{3} \mathrm{I}_{3} \mathrm{M}_{3} 0.58 \mathrm{dS} \mathrm{m}^{-1}$. It might be attributed to the addition of salts through application of increase dose of inorganic fertilizers. The maximum available Nitrogen $\left(\mathrm{kg} \mathrm{ha}^{-1}\right)$ of soil was found in the $\mathrm{T}_{3}\left(\mathrm{C}_{3} \mathrm{I}_{3} \mathrm{M}_{3}\right) 279.76$ followed by $\mathrm{T}_{2}\left(\mathrm{C}_{2} \mathrm{I}_{2} \mathrm{M}_{2}\right) 258.82$ and minimum values was found in control $\left(\mathrm{C}_{0} \mathrm{I}_{0} \mathrm{M}_{0}\right) 211.65$, respectively. Available NPK of soil was found significantly affected by the application of different level of compaction and micro-nutrient. It was also observed NPK of soil was gradually increased with an increase in different levels of compaction and micro-nutrient (Sarwar et al., 2010). The maximum available zinc in parts per million (PPM) of soil was found in treatment $\mathrm{T}_{3}$ $\left(\mathrm{C}_{3} \mathrm{I}_{3} \mathrm{M}_{3}\right) 0.65$ followed by $\mathrm{T}_{2}\left(\mathrm{C}_{2} \mathrm{I}_{2} \mathrm{M}_{2}\right) 0.56(\mathrm{PPM})$ and minimum values were found in control 0.33 (PPM). The availability of Zinc in soil was found Non-significant due to different level of compaction (Soil and Applied Zinc 2004).

Effect of micro-nutrients and farm yard manure on yield attributes of Maize: The dry weight of cob $(\mathrm{g})$ at 90 DAS, test weight (g/1000 grains) and yield (q/ha) were showed significant effect. The maximum dry weight of cob $(\mathrm{g})$ at 90 DAS, test weight $(\mathrm{g} / 1000$ grains) and yield $(\mathrm{q} / \mathrm{ha})$ were found in the treatment $\mathrm{T}_{2}$ viz., 154.43, 230.33 and 50.50, respectively. It was observed, the weight of cob were gradually increased with an increases in rate of compaction and micro- nutrient and farm yard manure. This improved growth was mainly due to increased soil nutrient supplying capacity and uptake by plants. Syed et al., (2009) reported that composite varieties differed significantly in dry weight of cob of maize. This might be due to the availability of $\mathrm{N}$ required for plant growth

Table 1. Effect of micro-nutrients and farm yard manure on soil physical properties.

\begin{tabular}{lcccc}
\hline Treatment & Bulk density (g/cc) & Particle density (g/cc) & Water holding capacity (\%) & Pore space (\%) \\
\hline $\mathrm{T}_{0}$ & 1.15 & 2.733 & 50.39 & 57.35 \\
$\mathrm{~T}_{1}$ & 1.16 & 2.356 & 53.06 & 53.10 \\
$\mathrm{~T}_{2}$ & 1.07 & 2.523 & 55.83 & 57.22 \\
$\mathrm{~T}_{3}$ & 1.09 & 3.010 & 58.23 & 63.40 \\
$\mathrm{~S}$. Em. $( \pm)$ & - & - & 0.33 & - \\
C.D. at 5\% & - & - & 0.93 & - \\
\hline
\end{tabular}


Table 2. Effect of micro-nutrients and farm yard manure on chemical properties of soil.

\begin{tabular}{|c|c|c|c|c|c|c|c|c|}
\hline Treatment & pH & $\begin{array}{l}\text { Soil EC } \\
\left(\mathrm{dSm}^{-1}\right)\end{array}$ & O.C (\%) & $\begin{array}{c}\text { A. N } \\
\left(\mathrm{kg} \mathrm{ha}^{-1}\right)\end{array}$ & $\begin{array}{c}\text { A. P } \\
\left(\mathrm{kg} \mathrm{ha}^{-1}\right)\end{array}$ & $\begin{array}{c}\text { A. K } \\
\left(\mathrm{kg} \mathrm{ha}^{-1}\right)\end{array}$ & $\begin{array}{l}\text { A. Zn } \\
\text { (ppm) }\end{array}$ & $\begin{array}{c}\text { A. S } \\
\text { (ppm) }\end{array}$ \\
\hline $\mathrm{T}_{0}$ & 7.17 & 0.45 & 0.43 & 211.65 & 16.71 & 154.30 & 0.33 & 11.48 \\
\hline $\mathrm{T}_{1}$ & 7.13 & 0.51 & 0.48 & 246.83 & 17.43 & 169.21 & 0.44 & 12.69 \\
\hline $\mathrm{T}_{2}$ & 7.10 & 0.55 & 0.55 & 258.82 & 17.87 & 177.92 & 0.56 & 13.72 \\
\hline $\mathrm{T}_{3}$ & 7.10 & 0.58 & 0.66 & 279.76 & 19.62 & 194.90 & 0.65 & 14.89 \\
\hline S. Em. $( \pm)$ & - & 0.02 & 0.02 & 14.59 & 0.14 & 1.54 & - & 0.22 \\
\hline C.D. at $5 \%$ & - & 0.07 & 0.04 & 21.70 & 0.24 & 3.11 & - & 0.44 \\
\hline
\end{tabular}

Note. A- (Available)

Table 3. Effect of micro-nutrients and farm yard manure on yield attributes of Maize.

\begin{tabular}{|c|c|c|c|}
\hline Treatment & Dry weight of cob (g) at 90 DAS & Test weight (g/1000 grains) & Yield $\left(q\right.$ ha $\left.^{-1}\right)$ \\
\hline $\mathrm{T}_{0}$ & 50.53 & 122.67 & 33.10 \\
\hline $\mathrm{T}_{1}$ & 102.97 & 222.00 & 42.15 \\
\hline $\mathrm{T}_{2}$ & 177.53 & 267.67 & 55.10 \\
\hline $\mathrm{T}_{3}$ & 154.43 & 230.33 & 50.50 \\
\hline S. Em. $( \pm)$ & 28.37 & 3.88 & 1.23 \\
\hline C.D. at $5 \%$ & 56.58 & 9.33 & 2.55 \\
\hline
\end{tabular}

and development (Ahmad et al., 2001). Application of organic matter showed increased DTPA-extractable concentrations of $\mathrm{Zn}, \mathrm{Fe}$ and $\mathrm{Mn}$. Micro nutrients (Fe, $\mathrm{Mn}$ and $\mathrm{Zn}$ ) of grain corn that ranged from $(36-65 \mathrm{mg}$ $\left.\mathrm{kg}^{-1}\right)$. These results were in agreement with Ali (2009). This study illustrated that the applied OM in to soil increased the concentration of $\mathrm{Zn}$ and $\mathrm{Mn}$ in grains and straw of maize plants. This might be due to the lowering in both $\mathrm{pH}$ and soil salinity values.

\section{Conclusion}

Integrated nutrient management is one of the best options for apply organic, inorganic fertilizers and mechanical practices to adapt higher in maize production. It not only enhances quantitative values of crop and also qualitative values of crop. The results from the study showed an important treatment combination for good soil health and higher yield in maize crop in alluvial soil at Allahabad region. On the basis of findings, the treatment combination $\left(\mathrm{C}_{2} \mathrm{I}_{2} \mathrm{M}_{2}\right) @ 125 \mathrm{~kg}$ Roller 6 times+@,50\% RDF (NPK+ZnSO $\left.{ }_{4}\right)+F Y M @ 5 \mathrm{t} \mathrm{ha}^{-1}$ $\left(\mathrm{T}_{2}\right)$ showed the best treatment for maize production. Therefore, we recommend to apply a combination $\left(\mathrm{T}_{2}\right)$ for higher maize production (the maximum dry weight of cob (g) at 90 DAS, test weight (g/1000 grains) and yield (q/ha) viz., 154.43, 230.33 and 50.50, respectively) in alluvial soil.

\section{REFERENCES}

Ahmad, R., Ranjha, A.M., Mehdi, S.M., Hussain, Sarfraz, M.J., M. and Hassan, G. (2001). Integrated use of organic manures and fertilizers in rice-wheat cropping system. Pakistan. J. Bio. Sci., 4: 184-186.

Ali, R. D. (2009). Determination of $\mathrm{Fe}, \mathrm{Cu}$ and $\mathrm{Zn}$ contents of wheat and corn grains from different growing site $J$. Animal and Veterinary Advances, 8(8): 1563-1567.

Aphale, S. L., Stokes, T. S., Black, C. R., Taylor, I. B. and Roberts, J. A. (2005). The role of root to shoot signaling in coordinating responses to soil compaction. Proceedings of the 32 $32^{\text {nd }}$ Annual Meeting of the Plant Growth Regulation Society of America, Newport Beach, California, USA, 20-23.

Blancher, R.W.(1986). Measurment of sulfur in soil and plant pp-450-490 in MA. Tobatabai (ed). Sulfur in agriculture Agron. Monogr.27 ASA, CSSA and SSSA, madison.WI.

FAO (2012). Available at: http://faostat.fao.org/site/567/ default.aspx

Fisher, R.A. (1960). Technique of analysis of variance. Hand book of agriculture statistics. Pp. 29110.

Husnjak, S., Filipović, D. and Košutić, S. (2002). Influence of different tillage systems on soil physical properties and crop yield. Rostlinná Výroba, 48: 249-254.

India maize summit (2014). Available at: http:// www.ficci.com/spdocument/20386/India-Maize2014 v2.pdf).

Jackson, M.L. (1958). Soil Chemical analysis. Prentice Hall, London.

Mulholland, B. J., Hussain, A., Black, C. R., Taylor, I. B. and Roberts, J. A. (1999). Does root-sourced ABA has a role in mediating growth and stomatal responses to soil compaction in tomato (Lycopersicon esculentum). Physiologia Plantarum.107: 3, 267-276.

Kumar, R., Rawat, K. S Singh, J., Singh, A and Rai, A. (2012 a). Soil aggregation dynamics and carbon sequestration. Journal of Applied and Natural Science, 5(1):250-267.

Kumar, R., Rawat, K.S and Mishra, A.K. (2012 b). Nanoparticles in the soil environment and their behaviour. Journal of Applied and Natural Science.4(2b):310-324.

Sarwar, N. S., Sukhdev, S.M., Munir, H.Z., Asif, N., Sadia, B. and Ghulam, F. (2010). Role of mineral nutrition in minimizing cadmium accumulation by plants (Review). J. Sci. Food Agric., 90: 925-937.

Syed, T.H., Shahid, I.Z., Waseem, A.A. and Waleed, B. Kh (2009). Growth and yield response of maize (Zea mays L.) to organic and inorganic sources of nitrogen. Pak. J. Life Soc. Sci., 7(2): 108-111.

Soil and Applied Zinc (2004). Available at: http:// corn.agronomy.wisc.edu/Management/pdfs/a2528.pdf

Tracy, B. F. and Zhang, Y. (2008). Soil compaction, corn 
yield response, and soil nutrient pool dynamics within an integrated crop-livestock system in Illinois. Crop Science. 48: 3, 1211-1218.

Unger, P.W. Kaspar, T.C. (1994). Soil compaction and root growth: a review. Agron. J , 86: 759-766.

Laiho, R. Penttilä, T. and Laine, J. (2004). "Variation in soil nutrient concentrations and bulk density within peat land forest sites," Silva Fennica, 38(1), pp. 29-41.

Lindsay, W. L. and Norvell W. A. (1978). Development of a DTPA soil test for zinc, iron, manganese, and copper Soil Sci. Soc. Am. J. 42: 421-428.

Olsen, S. R. Cole, C. V. Watanabe, F.S. and Dean, L.A. (1954). Estimation of available phosphorus in soils by extraction with sodium bicarbonate. United States Department of Agriculture, Circular 939.

Schjonning, P., Christensen, B. T. and Carstensen, B. (1994). Physical and chemical properties of a sandy loam receiving animal manure, mineral fertilizer or no fertilizer for 90 years. European Journal of Soil Science 45:257-268.

Subbiah, B. V. and Asija, G.L. (1956). A rapid procedure for estimation of available nitrogen in soils. Cur-rent Science 25: 259-263.

Walkley, A. and Black, I. A. (1934). An examination of Degtjareff method for determining soil organic matter and a proposed modification of the chromic acid titration method. Soil Sci. 37:29-37. 